\title{
Knowledge of Personal Hygiene among Food Handlers in Canteen at Faculty of Medicine, Universitas Padjadjaran, October to November 2012
}

\author{
Drasthya Zarisha, ${ }^{1}$ Budi Darmawan, ${ }^{2}$ Ardini S. Raksanagara, ${ }^{3}$ Elsa Pudji Setiawati ${ }^{3}$ \\ ${ }^{1}$ Faculty of Medicine Universitas Padjadjaran, ${ }^{2}$ Department of Nuclear Medicine Faculty of \\ Medicine Universitas Padjadjaran/Dr. Hasan Sadikin General Hospital, Bandung, ${ }^{3}$ Department of \\ Public Health Faculty of Medicine, Universitas Padjadjaran
}

\begin{abstract}
Background: Food borne diseases are caused by contamination of pathogenic microorganism and are still a major health problem throughout the world. There are 1,8 billion cases of diarrhea which mostly were caused by food contamination in 2005. Food handlers are at risk of contaminating microorganism towards food they handle. The process of transmission can be prevented by practicing good hygiene while processing and handling food. The objective of this study was assessing knowledge among food handlers regarding their personal and food hygiene at canteen in Faculty of Medicine, Universitas Padjadjaran.

Methods: A descriptive study was conducted during the period of October to November 2012 to 14 food handlers in the Canteen at Faculty of Medicine, Universitas Padjadjaran using 26 validated questions divided into 3 major parts, 14 questions for knowledge of hand washing, 9 questions for knowledge of utilization of clean water and 3 questions for knowledge of waste management. The scores were classified as good, moderate, and poor. Data were analyzed using frquency distribution.

Results: Majority of the respondents was male and common age group was 20-29 years old. Eight of the respondents were senior high school graduates. Based on working experience, majority of food handlers had been working for one and three years. None of the respondents had good knowledge. Only 12 and 2 respondents had moderate and poor knowledge, respectively.

Conclusion: None of the respondents had good knowledge regarding hand washing, utilization of clean water and waste management. Therefore, there is a need in providing more education about those aspects. [AMJ.2015;2(1):245-9]
\end{abstract}

Keywords: Clean water, food handlers, hand washing, knowledge, waste management

\section{Introduction}

One of the vision by the Ministry of Health of the Republic of Indonesia in 'Indonesia Sehat $2010^{\prime}$ is that Indonesian people live in a clean environment and have healthy behavior. ${ }^{1}$ Based on Indonesian Strategic Plan on Healthcare (RENSTRA) year 2010-2014, there is a need in shifting the health paradigm of Indonesian healthcare system from curative to preventive measure. ${ }^{2}$ One of the measures proposed by the Ministry of Health of Indonesia was Healthy and Clean Behavior (Perilaku Hidup Bersih dan Sehat/PHBS). It is one of the efforts to elevate people's health through preventive actions. $^{3}$

Furthermore, the Ministry of Health of Indonesia produced some indicators for PHBS measure based on social order of society, such as at home, at work, at school, at various health institution and at public place. ${ }^{3}$ This study focused on indicator of PHBS at work, since there are only few studies conducted regarding this measure in Indonesia and there are no reliable data that show proportion of workers who have been performing Healthy and Clean Behavior at work until now.

A person who has a direct contact with food and the utensils needs for preparing, processing until serving food were called food handlers. ${ }^{4}$ Food handlers were the people who are at risk of contaminating or transmitting microorganism toward food they handle, through hands, nose or mouth. ${ }^{5}$ Food borne illness are diseases caused by contamination of pathogenic microorganism in food consumed6 and still become a major public health problem throughout the world. ${ }^{7}$ There are

Correspondence: Drasthya Zarishai, Faculty of Medicine, Universitas Padjadjaran, Jalan Raya Bandung-Sumedang Km.21, Jatinangor, Sumedang, Indonesia, Phone: +62 85624944464 Email: zarisha.drasthya@gmail.com 
1,8 billion cases of diarrhea with majority of cases caused by food contamination in 2005 . $^{8}$ Indonesian Health Profile in 2010 recorded that diarrhea and gastroenteritis were ranked as the number one in-patient illness cause. ${ }^{9}$ The process of transmission can be prevented by practicing good hygiene while processing and handling food.

Canteen or cafeteria is an example of food retail business and service where most people consume food and drinks. ${ }^{10}$ It is also one of the working places of food handlers. Students and staffs as healthcare providers frequently visit canteen and consumed food and drinks; therefore they need to be aware about the possibilities of having food borne illness through unsafe process of food handling.

Knowledge is one of the predisposing factors that facilitate a person's behavior. ${ }^{11} \mathrm{~A}$ good knowledge of health (health literacy) can help a person to be aware on health and the community's health. ${ }^{1}$ Therefore, the main objective of this study was assessing knowledge among food handlers regarding their personal and food hygiene in canteen at
Faculty of Medicine, Universitas Padjadjaran which demonstrate their understanding toward PHBS indicators at working places.

\section{Methods}

A descriptive study was conducted in the Canteen at Faculty of Medicine, Universitas Padjadjaran and total of 14 food handlers were involved. Sampling method used was total sampling. The data were collected using questionnaire, during the period of October to November 2012. Inclusion criteria for the study were food handlers who were presently employed and the exclusion criteria were any food handlers who refuse to involve or being absent during the period of data collection. Prior to filling the questionnaire, respondents were given informed consent that included explanation and complete information about the objective of the study. Respondents gave voluntary consent regarding their involvement.

Questionnaire was pre-tested among food handlers with similar characteristics to the

Table 1 Characteristics of Food Handlers

\begin{tabular}{ll}
\hline \multicolumn{1}{c}{ Characteristics } & N=14 \\
\hline Gender & 8 \\
Male & 6 \\
Female & \\
Age (years old) & 6 \\
$20-29$ & 2 \\
$30-39$ & 3 \\
$40-49$ & 3 \\
$50-59$ & \\
Educational background & 2 \\
Elementary School & 4 \\
Junior High School & 8 \\
Senior High School & \\
Working experience (years) & 3 \\
1 & 3 \\
3 & 1 \\
7 & 2 \\
12 & 3 \\
13 & 1 \\
34 & 1 \\
\hline
\end{tabular}


Table 2 Knowledge of Respondents Regarding Hand Washing

\begin{tabular}{|c|c|c|c|}
\hline & Knowledge on Hand Washing & Correct answer $(n=14)$ & Incorrect answer $(n=14)$ \\
\hline 1. & Hand washing prior to handling food & 14 & 0 \\
\hline 2. & Hand washing prior to serving food & 14 & 0 \\
\hline 3. & Correct method on hand washing & 13 & 1 \\
\hline 4. & Purpose of hand washing & 13 & 1 \\
\hline \multirow[t]{8}{*}{5.} & Correct time of hand washing & & \\
\hline & After urinate & 12 & 2 \\
\hline & After defecation & 14 & 0 \\
\hline & After handling money & 10 & 4 \\
\hline & Before serving food & 13 & 1 \\
\hline & After smoking & 8 & 6 \\
\hline & $\begin{array}{l}\text { After coughing, sneezing or shaking } \\
\text { people's hand }\end{array}$ & 10 & 4 \\
\hline & After throwing or cleaning rubbish & 11 & 3 \\
\hline 6. & $\begin{array}{l}\text { Knowledge regarding dirt that could } \\
\text { be cleaned with washing hand }\end{array}$ & 13 & 1 \\
\hline 7 & Step(s) of hand washing (1) & 13 & 1 \\
\hline 8 & Step(s) of hand washing (2) & 13 & 1 \\
\hline
\end{tabular}

sample and was analyzed using computer. Alpha Cronbach test was carried out and the reliability coefficient was $0.91 .^{12} \mathrm{Few}$ questions were modified and excluded to maximize reliability. Twenty-six questions were divided into 3 major parts, 14 questions for knowledge of hand washing, 9 questions for knowledge of utilization of clean water and 3 questions for knowledge of waste management.

The scores derived from the questionnaire were calculated using computer. Mean and standard deviation were calculated from the scores and the results classified as good, moderate, and poor. ${ }^{13}$ Data were analyzed using frequency distribution

\section{Results}

Majority of the respondents were male and common age group was 20-29 years old. Eight of the respondents were senior high school graduates. Based on working experience, majority of food handlers had been working for one and three years in Canteen at Faculty of Medicine, Universitas Padjadjaran. (Table 1)

Furthermore, according to the knowledge of handwashing procedures, all respondents understood the need to wash their hands before handling and serving food to the costumers. Thirteen respondents were aware about the correct hand washing procedure, and understood the steps of good hand washing procedure. Only eight of the respondents had good knowledge regarding the importance of hand washing after smoking.

All respondents understood the need to use clean water for washing raw food before cooking it. Only 9 respondents were aware about the importance of using clean and safe water during the process of making costumer's drinks, and only 10 respondents were aware about using clean water in making ice cubes. (Table 3).

The knowledge of waste management was asked using 3 questions which were how to process the waste, to prevent dissemination of dirtand to clean the rubbish bin regularly. In this study, all subjects understood the importance of cleaning rubbish bin regularly and also the correct way to prevent dissemination of dirt into working area. (Table 4)

Personal hygiene knowledge among the food handlers was graded into good, moderate, and poor. This study found that none of the respondents reached good knowledge, also only 12 respondents had moderate knowledge and 2 respondents had poor knowledge 
Table 3 Knowledge of Respondents regarding Clean Water Utilization

\begin{tabular}{llll}
\hline \multicolumn{1}{c}{$\begin{array}{c}\text { Knowledge on Clean Water } \\
\text { Utilization }\end{array}$} & Correct answer (n=14) & Incorrect answer (n=14) \\
\hline 1 & Clean water to wash raw food material & 14 & 0 \\
2 & Characteristics of clean and safe water & 13 & 1 \\
3 & Characteristics of clean and safe water & 13 & 1 \\
& $(2)$ & & \\
4 & Correct time to use clean water & 13 & 1 \\
& Washing raw vegetables and fruits & 12 & 2 \\
& Washing cooking utensils & 13 & 1 \\
& Washing raw food & 12 & 2 \\
& Added to processed food & 10 & 4 \\
& Making ice & 9 & 5 \\
Making drinks & &
\end{tabular}

\section{Discussions}

One out of the five main risk factors of food borne illness is bad personal hygiene in food retail services as being stated in the Center for Disease Control and Prevention's report 'Surveillance for Food Borne Disease Outbreaks-United States'. ${ }^{10}$ In this study, most respondents were males. A study conducted in hospital and medical college in Solapur, India ${ }^{5}$ also stated that their majority of study populations were males. Eight out of 14 food handlers have senior high school graduates as their education background. Majority of the subjects aged are 20-29 years old. A study conducted by Nee et al. ${ }^{14}$ showed that mostly food handlers have senior high school graduates as their educational background.

Twelve out of fourteen respondents have moderate knowledge, but none of the respondents scored well or in another word have good knowledge regarding Healthy and Clean Behavior. This finding is similar to several studies regarding personal hygiene which were conducted among food handlers in other countries. ${ }^{5,14}$

All respondents understood the needs of having their hand washed after defecate and before they handle food. Thirteen respondents were aware that they need to wash their hands before serving the food and this result is consistent with the finding from the study conducted by Arunrao et al. ${ }^{5}$

All respondents realized the importance of washing raw food using clean and safe water. Water obtained from unhygienic sources could be contaminated by microorganisms which are pathogenic to the human being..$^{15} \mathrm{~A}$ study conducted by Kitagwa ${ }^{16}$ observed that only $27 \%$ of their study population knows the importance of using safe and clean water to prevent contamination of microorganisms in food.

Overall, the knowledge regarding waste management among the respondents were good because all respondents were aware about the correct way to prevent dirt dissemination and regularly cleane the rubbish bin. Based on $\mathrm{WHO}^{15}$, these 2 measures are important to prevent contamination of food.

Eight out of fourteen respondents who have moderate knowledge regarding the cleanliness also have senior high school graduates as their education background. Having high level of education might influence the capability

Table 4 Knowledge of Respondents regarding Waste Management

\begin{tabular}{llcc}
\hline & Knowledge on Waste Management & Correct answer $(\mathbf{n = 1 4})$ & Incorrect answer $(\mathbf{n = 1 4})$ \\
\hline 1 & Correct way of processing waste & 12 & 2 \\
2 & Way to prevent dissemination of dirt & 14 & 0 \\
3 & Cleaning rubbish bin regularly & 14 & 0 \\
\hline
\end{tabular}


of the respondents in having better health knowledge. ${ }^{17}$ The ability to read, speak, write or listen are the fundamentals of a person's ability to have a better understanding in their personal health. ${ }^{17}$

Healthcare providers are the majority of the consumers in this canteen and they should understand and give concern about food borne illness and the way it transmits among food handlers. ${ }^{5}$ The result of this study showed that there are no respondents who have a good knowledge regarding PHBS. Therefore, there is a need in providing more education about personal hygiene which focuses on PHBS to improve the health knowledge of the food handlers whom are involved in preparing food. This intervention can be done by all faculty members, particularly the students and other faculty members who are health physicians and healthcare workers.

Limitation of this study is during the study there was no evidence of diarrhea cases and food poisoning among students and lecturers who consumed food from those respondents. Furthermore, further study should be conducted with more samples

\section{References}

1. Notoatmodjo S. Promosi kesehatan dan ilmu perilaku. Jakarta: Rineka Cipta; 2007.

2. Kemenkes RI. Rencana Strategis Kementerian Kesehatan Republik Indonesia. Jakarta: Kementerian Kesehatan Republik Indonesia; 2010.

3. Kemenkes RI. Peraturan Menteri Kesehatan Republik Indonesia: Pedoman Pembinaan Perilaku Hidup Bersih dan Sehat. Jakarta: Kementerian Kesehatan Republik Indonesia; 2011.

4. Kemenkes RI. Keputusan Menteri Kesehatan RI tentang Persyaratan Hygiene Sanitasi Jasaboga. Jakarta: Kementerian Kesehatan Republik Indonesia; 2003.

5. Takalkar AA, Kumavat AP. Assesment of personal hygiene of canteen workers of government medical college and hospital, Solapur. National Journal of Community Medicine. 2011;2(3):448-51

6. Slamet JS. Kesehatan lingkungan. Jogjakarta: Gadjah Mada University Press; 2004.
7. US Food and Drug Administration. Hazard analysis \& critical control points (HACCP). Silver Spring: US FDA; 2004. [Cited 2012 April 24] available from: http://www.fda. gov/Food/GuidanceRegulation/HACCP/

8. WHO. Fact sheet No 237: food safety and foodborne illness. 2007 [Cited 2012 April 24]: available from: https:// foodhygiene 2010 .files.wordpress. com/2010/06/who-food_safety_factsheet.pdf

9. Kemenkes RI. Profil Kesehatan Indonesia 2010. Jakarta: Kementerian Kesehatan RI; 2010.

10. US Department of Health and Human Service, Food and Drug Administration, Center for Food Safety and Applied Nutrition. Managing food safety: a manual for the voluntary use of HACCP principles for operators of food service and retail establishment. 2006. [Cited 2012 April 24] available from:http:// seafood.oregonstate.edu/.pdf\%20Links/ Managing \% 20 Fo od $\% 20$ Safe ty $\% 20$ -\%20A\%20Manual\%20for\%20the $\% 20$ Voluntary\%20Use \%20of\%20HACCP\%20 Principles $\% 20$ for $\% 200$ perators $\% 20$ of\%20Food\%20Service.pdf

11. Notoatmodjo S. Promosi kesehatan: teori dan aplikasi. Jakarta: Rineka Cipta; 2007.

12. Dahlan MS. Besar sampel dan cara pengambilan sampel. Jakarta: Salemba Medika; 2010.

13. Arikunto S. Prosedur penelitian: suatu pendekatan praktik. Jakarta: Rineka Cipta; 2006.

14. Nee SO, Sani NA. Assessment of knowledge, attitudes and practices (KAP) among food handlers at Residential College and Canteen regarding food safety. Sains Malaysiana. 2011;40(4):403-10.

15. WHO. Five keys to safer food manual. France: WHO Press; 2006.

16. Kitagwa WG, Bekker JL, Onyangp RO. An assessment of knowledge, attitudes and practices of food handlers in food kiosks in relation to food hygiene in Eldoret, Kenya. IJCR. 2012;4(04):127-38.

17. Baker DW. The meaning and the measure of health literacy. J Gen Intern Med. 2006; 21(8):878-83. 